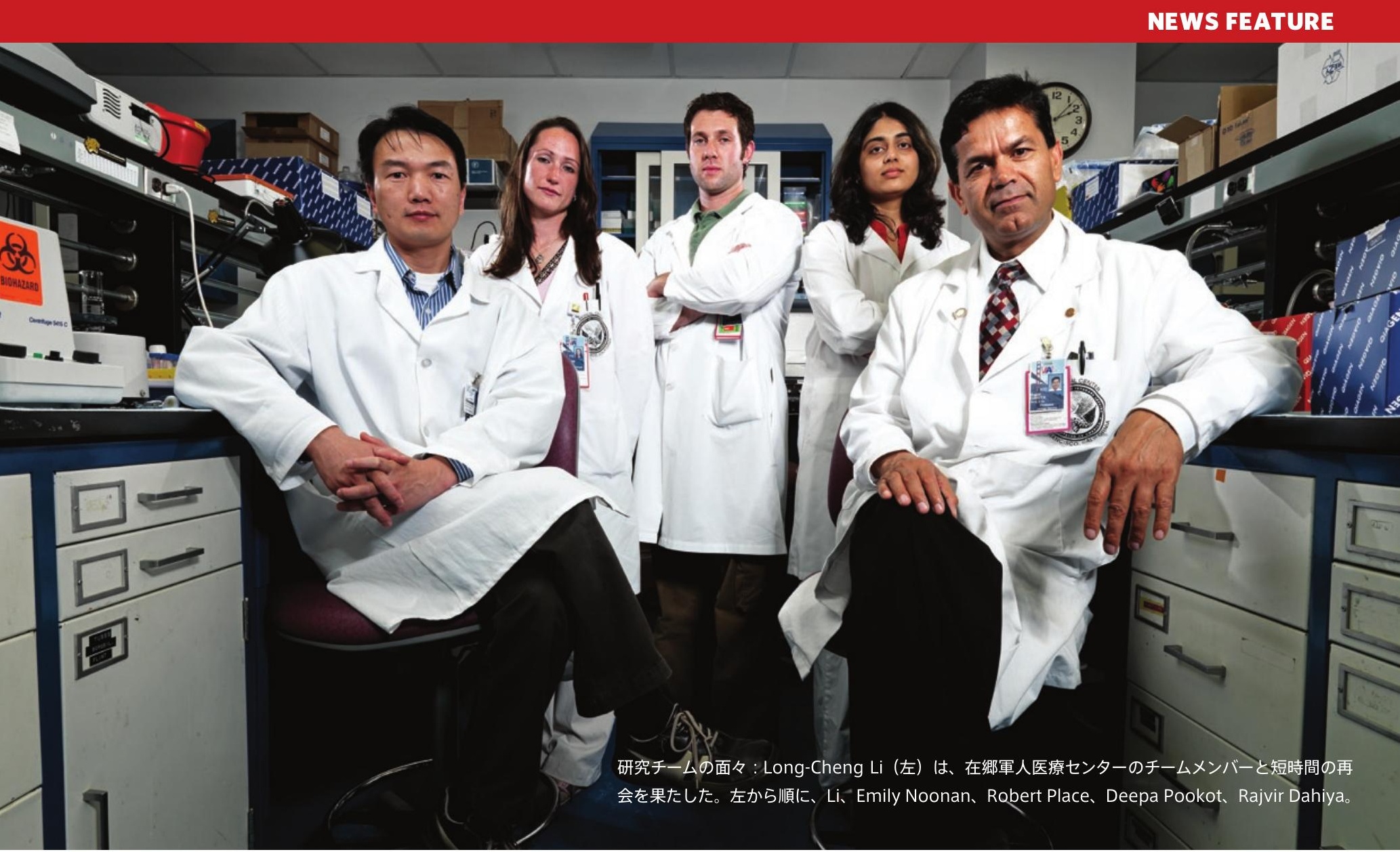

\title{
Hitting the on switch
}

\section{マイクロRNAによる遺伝子活性化をめぐって}

Nature Vol.448 (855-858) / 23 August 2007

RNA干渉のまったく新しい側面を示す知見が、サンフランシスコの研究チームによって報告された。革新的な分野にさ らに革命を起こそうとする彼らの試みについて Erika Checkが取材報告する。

「完璧に見える」。ニター画面を横切る 滑らかな軌跡を見つめながら、Robert Placeはそうつぶやいた。「こんなにう まくいくとは思わなかった」。

Place は、在郷軍人医療センターと カリフォルニア大学サンフランシスコ校 (UCSF) に籍を置く分子生物学者で、今 しも分光光度計を使って一連の試料の純 度を測定しているところだった。どの試 料にも、わずか 1 滴分のマイクロ RNA (miRNA) が含まれている。 miRNAと
は、遺伝子の発現を抑制する一種の遺伝 子制御因子である。あるいは、今のとこ ろそういうことになっているといってお こう。Placeが没頭しているのは、その miRNAの概念を覆すような論文の投稿 に絶対必要な最終実験である。彼と同僚 であるUCSFのLong-Cheng Liは、細 胞内で遺伝子発現を抑制するのではなく 促進させる作用をもつ miRNAがあるこ とを見つけたと考えている。

彼らの研究は、生物学で今最もホット
な話題の 1 つである、RNA干渉の基本 概念を摇るがすものかもしれない。RNA 干渉の研究では、短いRNAによる遺伝 子の発現制御について調べられている。 Placeは、自分の行っている実験が他の 研究者によって厳しく審査されるはずで あり、したがって実験を完璧にやり遂げ ねばならないことをよく承知している。 そして彼自身の見るかぎり、実験は完璧 だ。分光光度計は一連の完璧なカーブを 表示しており、不純物がないことを示し 
ている。それは、彼と同僚が落胆と高揚 を繰り返した苦節の 3 年間を経て、やっ と手にした報酬といえるかもしれない。

この 50 年というもの、DNAにばかり 注目が集まって、DNAの従兄弟にあたる RNAが生体内で果たしている幅広い役割 には目が向けられてこなかった。研究者 たちがこのことに気づいたのは、今世紀 に入ったころのことだ。古い考え方では、 DNAには生命の指令書が書き込まれて おり、タンパク質はその指令書を実行に 移す役で、RNAは両者の橋渡し役に過ぎ ないとされてきた。現在では、細胞がゲ ノムに書き込まれている指示書を読み取 る機構の制御に、RNAが広くかかわって いる可能性が明らかになっている。

RNAに対する認識が大きく変化し始 めたのは、1998年のことだ。線虫にお いて、短い2本のRNAの鎖がDNA と同 じように対になって、互いにしっかり結 合して短い二本鎖を作り、特異的な遺伝 子の発現のスイッチを切るという発見が なされたのである1。RNA干渉という研 究領域の誕生である。この発見は2006 年のノーベル医学・生理学賞に輝いた。

2001 年になって、哺乳類でもRNA干 渉が機能していることが発見された 干渉は、「低分子干渉RNA（siRNA)」ま たは「ショートへアピンRNA（shRNA)」 によって引き起こされうることがわかっ た。どちらの場合も、RISC (RNA-induced silencing complex; RNA 誘導サイレン シング複合体）というタンパク質複合体 が「ハサミ」として使われ、遺伝子か ら細胞質のタンパク質産生装置まで情報 を送り届ける長いメッセンジャーRNA (mRNA) 分子を切り刻む。生成された 低分子RNAは、相補的な塩基配列をも つmRNAを標的にする。RNA干渉では、 この mRNAを破壞することで遺伝子から タンパク質生成への過程が途中で止めら れてしまう。現在、過剩に活性化した遺 伝子を活動停止させる必要のある疾患に 対して、SiRNAやShRNAを用いた臨床 試験が行われているところである 3

続いてmiRNAが発見された。miRNA もRNA干渉現象を引き起こすが、SiRNA
やshRNA と違って、細胞のDNAにもと もとコードされている。ヒトゲノムでは これまでに 500 種類余りの miRNAが見 つかっている4。これらはsiRNAと同じ ように㗢くことができ、mRNAの切断に 使われるタンパク質複合体も同じである。 しかし、大半の miRNA は、情報伝達を 封じるか、分解用の標識付けをするのに とどまっていて、mRNAを切り刻むよう なことはしていない（右図を参照）。

これらの技術はいずれもまだ歴史が 非常に浅く、登場したのは2004年のこ とだ。そのころLiは、サンフランシスコ 在郷軍人医療センター泌尿器科の Rajvir Dahiya の研究室でRNAの研究を始めて いた。当時はLi自身も泌尿器科医の 1 人 として、エピジェネティクスを研究して いた。エピジェネティクスとは、ゲノム に安定な修飾を加えることによって、塩 基配列を变えることなく、遺伝情報の読 み取り方を変化させる仕組みである。

Liが特に興味をもったのは、DNAメ チル化という、DNAの一部領域にメチル 基という化学的な標識を付ける現象だっ た。メチル基の標識は往々にして近くに ある遺伝子を「沈黙」させる。通常であ れば腫瘍を抑制するはずの遺伝子がそう した影響を受けると、最悪の結果につな がることもある。そこでLiは、この過 程を逆行させる方法を見つけ出そうと考 え、mRNAを使ってメチル化を制御する 方法を試そうと決めた。当時、植物では すでに10年前に報告がなされていた 彼が知るかぎり、動物でこの方法はまだ 使われていなかった。

\section{予期せぬ活性化}

Li は、E-カドヘリンという腫瘍抑制因子 タンパク質をコードする遺伝子の上流に 位置する、プロモーターとよばれるDNA の発現を調節する配列に相補的な二本鎖 RNAの製品を2点購入した。そして、同 僚のHong Zhaoがその二本鎖RNAを 2 系列の前立腺がん細胞に添加して、E-力 ドヘリンの発現にどう影響を及ぼすかを 調べた。3日後、Zhaoはショッキングな 結果に驚いた。E-カドヘリンの值が4〜
14 倍に上昇していたのである。「信じら れなかった」とLiはいう。

この研究結果は、これまで低分子の 二本鎖RNAについて報告されてきたこ とを根底から覆すものだった。これまで は、遺伝子発現の抑制作用しか報告され ていなかったからだ。Liは、RNA干渉に 関する教科書の記述を書き換えることに なるかもしれない、そして新しい治療法 の可能性を開くことにもつながる現象に 出くわし、激しく動摇したという。

Li は実験を繰り返したが、何度やって も結果は同じだった。彼は、VEGFとp21 という別の2つのがん関連遺伝子も、二 本鎖RNAによって活性化されうること を見つけた。それは動か女証拠のように 思えた。少なくとも彼が調べた前立腺が ん細胞では、低分子二本鎖RNAによっ て遺伝子が活性化されたのである。「そ れは簡単に観察できた。だから、どうし てこんなに長い間気づかれずにいたのか 不思議に思えた」としiは語る。

しかし、これまでだれも気がつかな かったらしい。そこでLiは、ほかの研究 者を納得させるためには、スキのない実 験を組み立てねばならないと思った。と ころが、それがいかにむずかしいかを痛 感したのは、2004年8月、Scienceに初 めて論文を投稿したときだった。投稿論 文はすぐに却下されてしまったのである。 彼は、同年12月にNatureにも投稿した が、それも却下され、2005年4月に新 しいデータを盛り込んだ論文を同誌に再 投稿した。2005年5月にはカリフォルニ ア州アナハイムで開催された米国癌学会 (AACR) の年次総会でその知見を発表し たが、会場の反応は冷ややかだった。懷 疑的な質問を山ほどされた」とLiはいう。 そして、再投稿からかなり時間が経った 2005年12月、Natureからまたしても却 下されたのである。何らかの作用機序を 示す証拠がなく、結果が十分な説得力を もたない、と通告されたのだという。

しiは研究の進め方に確信をもてな くなっていた。そこへ思いがけなく、 Placeという心強い助っ人が、研究室に 加わった。2005年10月のことであっ 
た。PhDを取得したばかりのPlaceは、 Liの知見の目新しさに興奮を覚えた。彼 には、しなければならない重要な分子生 物学的研究が山積みになっていることが わかった。彼は、この新しい知見に懐疑 的な人々を十分に納得させる証拠を得る ための実験に取り組んだ。例えば、Liや 専属テクニシャン（実験助手）のDeepa Pookotを助けて、免疫ブロット法とよ ばれる分析を完璧に仕上げた。この分析 で、タンパク質を検出し、RNA活性化 (RNA activation；RNA干渉と逆の作用 をさす言葉）によってE-カドヘリンその
他のタンパク質の量がどれくらい上昇す るかを調べることができる。

\section{細かい点を詰める}

Place とLiは、RNAを標的とした遺伝子 活性化（RNA 活性化）の背景にある仕 組みについても考察を始めた。論文を考 査した編集者や査読者が問題視する障害 だったからである。もし、遺伝子サイレ ンシング (発現抑制) と同じ道筋でRNA 活性化が働いているなら、その効果を引 き出したRNAの塩基配列が問題になる はずであり、実際にそうであることを 2
人は見つけた。21塩基から成る配列の 一端にある塩基 5 個を変えることで、遺 伝子を不活性化できたのである。

Placeと Li は、ダイサーなど、サイレ ンシングにかかわっているものと同じ重 要なタンパク質のいくつかが、RNA活 性化にも使われることを見つけた。ダ イサーは、二本鎖RNAを細切れにして、 RISCが取り込めるようにするのである。 2 人はいちばん効率よく機能するRNAを 見つけ出そうと、RNA活性化の実験を 始めた。「我々は、最適なRNA活性化が できるようにRNA 二本鎖の修飾を行い、

\section{干渉を越えて}

RNA干渉 (RNAi) は過去10年間で最もホットな分野の1つとなってきた。トリガーとよばれる、裏方役のさまざまな 短いRNAついて詳細が明らかになるにつれて、RNA干渉が核内でどのように機能して転写を止める(あるいは可能 性として、転写を増幅する)かといった、より多くの疑問が出てきている。

\section{pre-miRNA}

m i R N A 前 駆体 (pre-miRNA)は核内か ら細胞質に送られる。こ れらは普通、すべて の塩基が完全に一 致しなくても、ルー プ部分で折り返して 二本鎖となったへア ピン構造をとる。
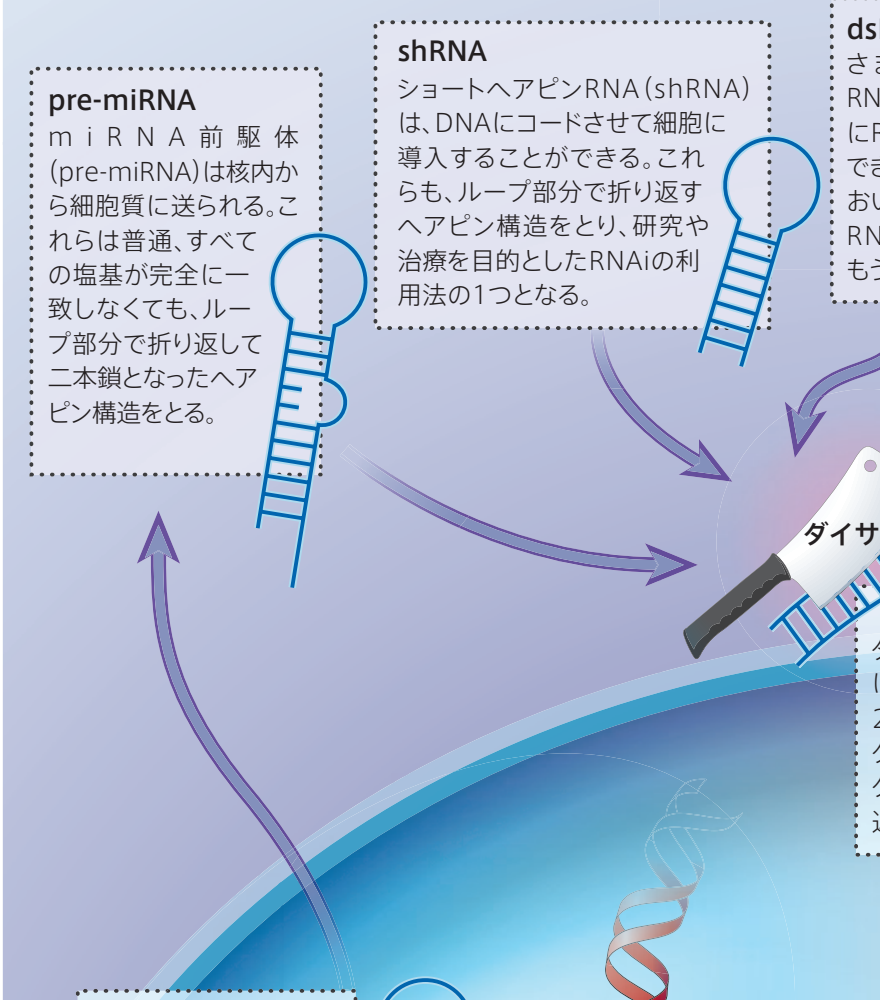

\section{pri-miRNA}

プライマリーmiR NA (pri-miRNA)はゲノムか ら転写され、タンパク質に： よるプロセシングを受けて pre-miRNAとなる。

\section{shRNA}

ショートヘアピンRNA (shRNA) は、DNAにコードさせて細胞に 導入することができる。これ らも、ループ部分で折り返す ヘアピン構造をとり、研究や 治療を目的としたRNAiの利 用法の1つとなる。

\section{dsRNA}

さまざまな長さの二本鎖 RNA(dsRNA)を使って、細胞 にRNAiを開始させることが できる。これは、動物細胞に おいて、研究や治療目的で RNAi反応を開始させる もう一つの方法となる。

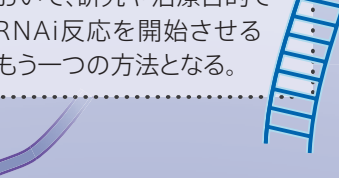

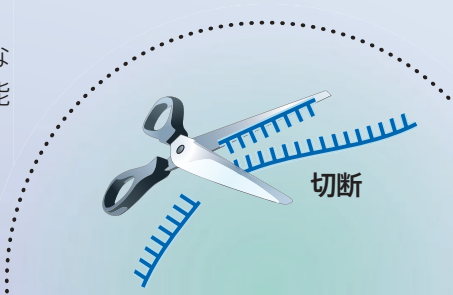

翻訳

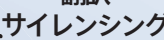

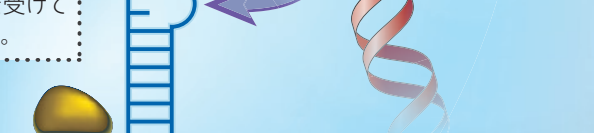
ダイサーによってプロセシングを受けた
RNAの中には、核內へ移行して遺伝子プロ
モーターを標的とするようにみえるものが
あるっこれらのRNAはメッセンジャ-RNA
が遺伝子から転写されるのを止めること
ができるが、その過程はよくわかっていな
い。ショ一トRNA塩基配列の中に、遺伝子を
活性化させるものが実際にあるのか、すな
わちRNA活性化とよばれる過程があるか
どうかは、それ以上によくわかっていない。

\section{miRNA遺伝子}

3種類の二本鎖RNAはどれも、 ダイサーによるプロセシングを受 ける。ダイサーとは、RNA鎖をほぼ 21塩基の長さまで切断するタンパ ク質であり、RISCとよばれるタンパ ク質複合体にそのRNA鎖を取り 込ませてRNAiの準備を整える。

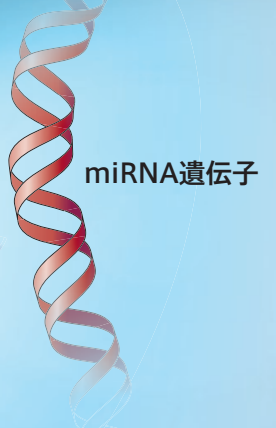

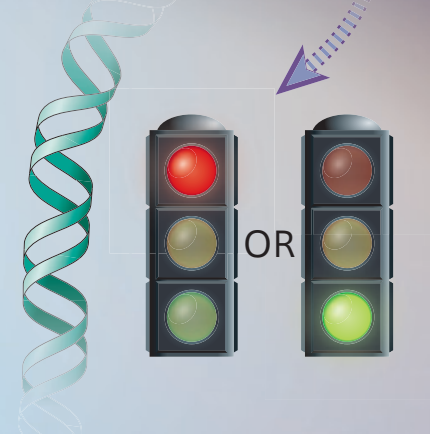


二本鎖の化学構造の微調整に取りかかっ た」とPlaceは回想した。「我々は足並 みをそろえて、あうんの呼吸で研究を進 めるようになった」。

Liは、Placeによる分子生物学実験の 成果も加えた論文をScienceに再投稿し たが、またしても却下されてしまった。 しiが受け取った通知には、この研究は「重 大なパラダイムシフトを提示していると 考えられる」ので、提出された証拠では 不十分だとあった。編集部は再び作用機 序の説明を求めてきた。

そこで2006年6月にLiは、ニューヨー ク州のコールド・スプリング・ハーバー研 究所で開催された会議で、RNA制御研究 のリーダーたちと話をした。Liの記憶で は、ホワイトヘッド生物医学研究所（マ サチューセッツ州ケンブリッジ）のDavid Bartel に、RNA活性化（RNA抑制では なく）があり得るかどうかを尋ねた。 Li によれば、Bartelは、そうは思わないと いったらしい。Bartelは、そのときの会 話を思い出せないといい、「私はおそら く、活性化の証拠が実際どの程度確実な のかを見極めようとしたのだと思う」と 説明した。Liは、そこでは分野外の若手 研究者にすぎず、自分の知見を発表する ことはできなかった。

業を煮やしたLiは、選考基準がNature やScienceほど厳しくない、とあるオン ライン・ジャーナルに知見を送った。だ が、Dahiyaは、この研究が世に知られ ずに埋もれてしまうのではないかと考え、 『全米科学アカデミ一紀要』に投稿する ようLiを説得した。2006 年の8月、Li の研究チームは同紀要に研究論文を投稿 し、ようやく突破口を開いた。同紀要は 数週間で査読をすませ、この論文を 11 月のオンライン版に掲載した ${ }^{6}$ 。その 2 か 月後、Liたちの研究成果の正当性が裏付 けられた。ダラスにあるテキサス大学サ ウスウエスタン医療センターの生化学者 David Coreyが率いる別の研究チームが、 Nature Chemical Biology で、Liたちの成 果と基本的にそっくり同じ研究論文を発 表したのである7。「私たちにとっては本 当にありがたいことだった」とPlaceは
語った。「それまではだれもが、私たちの ことを変人扱いしていたのだから」。

在郷軍人医療センターに戻ると、Liは、 自身の研究室をUCSFに移動する準備を しながらも、Placeと緊密に連携をとっ て研究を進めた。彼らはすでに、RNA活 性化の仮説の裏付けになると期待できる 一連の実験を練り上げていた。塩基配列 の変化の中には、RNAを役に立たなく させるものもあれば、RNA活性化をう まく微調整するものもある。この「トリ ガ一」分子は、標的とする塩基配列に正 確に適合する必要はなく、また、二本鎖 RNAにわずかな調整を施すことで活性化 は弱まる。そこでPlaceとLiは、E-カド ヘリンを活性化しそうな miRNAを探し 始めた。miRNAの存在によって、RNA 活性化が自然現象であるとは実証できな いだろうが、miRNAがゲノムにコード されていることを考慮すれば、事例の裏 付けにはなると考えられた。

Place と Li は バイオインフォマティク スの手法を使って、ヒトゲノムで、E-力 ドヘリンのプロモーター配列とほぼ相補 的な配列をもつmiRNAを探した。する と、わずかながら候補分子が見つかった ので、それらを前立腺がん細胞に導入 してみた。この実験はあまりに簡単であ り、そううまくことが運ぶわけがないと 期待していなかった。ところが、予想に 反してうまくいったのである。2人は、 miR-373という miRNAがE-カドヘリン の発現を増大させることを見つけた。「こ の実験が成功したとき、我々はすっかり 興奮してしまった。RNA活性化が自然界 に存在する機能である可能性が出てきた からだ」とPlaceはいった。

\section{方向性は間違っていない}

ところが、それでもまだ証拠が不十分 だった。そこでPlaceは、miRNAの前 駆体を設計した。miRNAの生合成モデ ルによれば、この前駆体は miRNAその ものと同じように機能するはずであり、 実際うまく機能した。Placeはほかに、 ダイサーをノックアウトした場合には miR-373 が機能を止めることや、ダイ
サーがE-カドヘリンのプロモーターに似 た配列をもつ別のタンパク質を活性化す ることも見つけた。これらの実験はすべ て、miRNAがこの干渉経路を使って遺 伝子を活性化している可能性があるとい う説を裏付けていた。それは、Placeと Liのめざす方向が間違っていないことを 強く物語っていた。今年8月6日、彼ら は研究論文を Nature Chemical Biologyへ 投稿した。

目下の問題は、この研究がどんな受 け止め方をされるか、である。David Coreyが証言するように、多くの研究者 はRNA活性化についてまだ懐疑的である。 「この前、ある会議でRNA活性化につい て話したとき、この分野の著名な研究者 2人が私を激しく非難して、それは間違っ ているといってきた」とCoreyはいう。 「我々は、腹を立てて書いた文章としか思 えないような助成金交付の考査評や論文 の査読評を受け取った。我々のデータを もっとよく見てほしいものだと思う」。

実際のところ、RNA活性化という考 え方はRNA干渉のドグマに反するので、 場合によっては劣勢のようにみえる。 RNA干渉は、それ自体まだ非常に新し い研究領域なのに、すでにちょっとした 硬直化を起こしているようだ。Placeは、 生物学のメッセージ・フォーラム (インター ネット掲示板）を閲覽していて、ほかの 研究者（その多くは大学院生）もRNA 活性化の証拠を見つけていることに気づ いた。ところが、彼らはその証拠を無視 するよう指導されていた。

マサチューセッツエ科大学 (米国ケン ブリッジ）に研究室をもつノーベル賞 受賞者の生物学者、Phillip Sharpは、 RNA干渉に関するさまざまな研究を開 拓した人物であり、RNAが関与する遺 伝子活性化の可能性を認めている。しか し、「私が目にした実験結果からは証明 できない」という。彼は、学術誌編集部 からの要求を繰り返すかのようにこう いった。「もし、彼ら（Liたち）が権威 ある学術誌への論文掲載を望むなら、こ の問題に関する今後の論文で作用機序に 取り組むべきだと思う」。 


\section{新たな道筋}

この分野の研究は日進月歩で、こうした 要求は当然であり、何らかの作用機序を 示す証拠を示すことが、Li とPlaceが挑 むべき大きな課題である。RNA活性化は 抑制が姿を変えたものにすぎない、と示 唆した研究者もいる。偶然に、上流のリ プレッサーがサイレンシングを受けたか、 別のサイレンシングRNAを阻害した結果 ではないかというのである。Liたちは、 実験からこれらの可能性を排除すること はできないが、こうした機構が偶然に作 用することは現実的ではないと語る。例 えば、特定の遺伝子のプロモーターを標 的にすることで、その遺伝子の活性化を 思い通りに引き出すことが可能だからだ。

すでに知られているサイレンシング経 路と、Liたちの観察したRNA活性化現 象の間には、興味深い違いがある。サイ レンシングは、数時間以内に引き起こさ れ、およそ7日で終わる。ところが、活 性化は数日かかるようにみえ、数週間に わたって続く。こうした動態の違いは、 何か未知の過程が関与していることを示 唆していると、Place はいう。「RNA活 性化はRNA干渉を別のよび名でよんで いるだけだといわれるが、明らかに違う ものである」。

遺伝子プロモーター領域でRNAによ る制御がどのように機能するのかにつ いても、大きな疑問がまだいくつか残つ ている。従来の干渉経路では、RISCが、 SiRNAまたはmiRNAを細胞質内にある 標的の mRNAのところまで導く。とこ ろが、プロモーター制御のためには、低 分子RNAが、DNAが転写される場であ る核内に進入しなければならない。核内 への進入がサイレンシング過程で起こっ ていることを示す証拠は増えつつある が、その作用機序もやはり不明である。

2004 年に2つの研究グループが、遺 伝子プロモーター領域を標的とする SiRNAを核内に送達した場合に、遺伝子 の発現を抑制できることを示す論文を発 表した。一方のグループは提出した論文 をその後撤回したが、もう一方のScience に発表したグループは8、発現抑制に伴っ

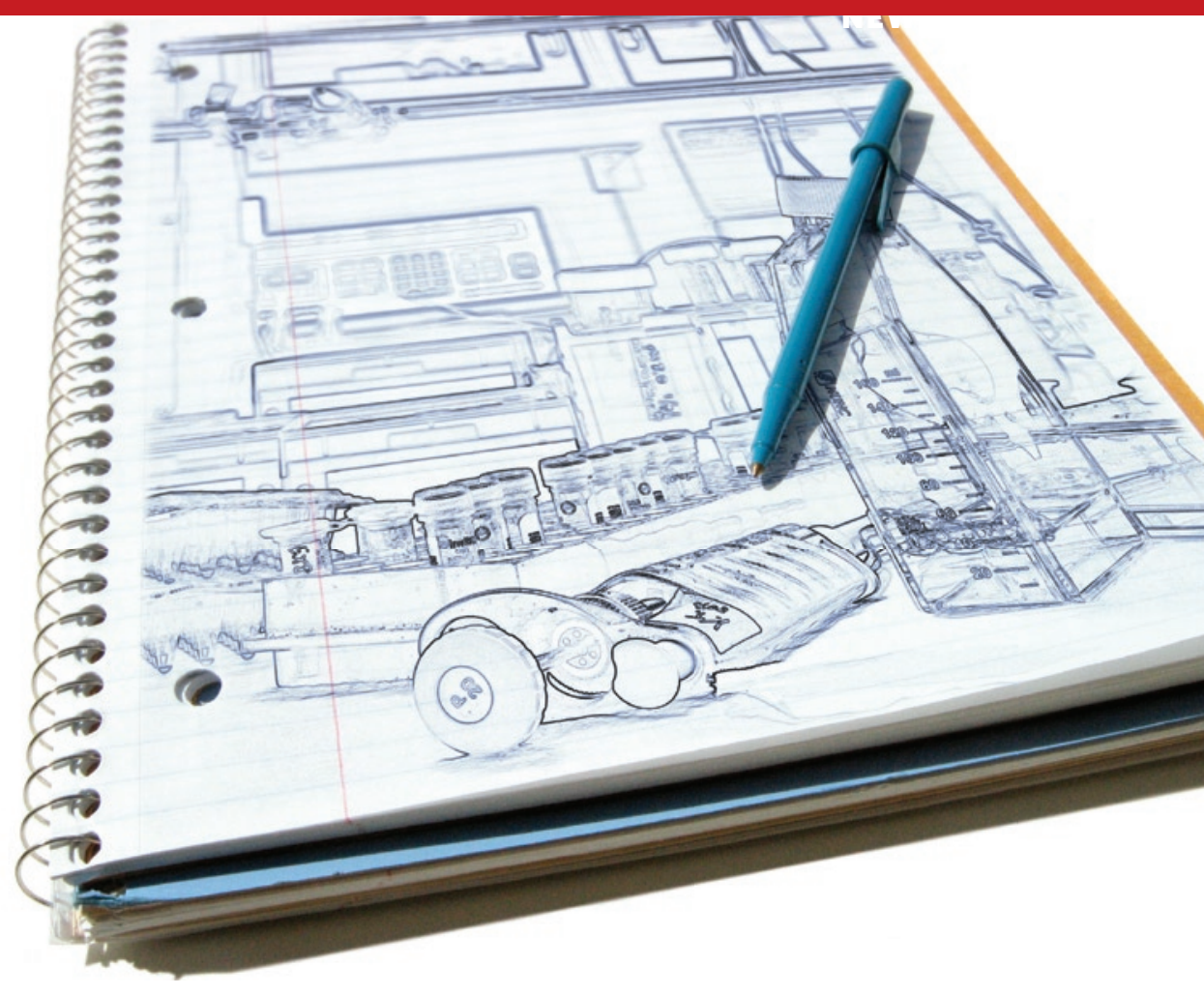

て、サイレンシングに関連したエピジェ ネティックな標識付加があることを示し た。その論文の著者の 1 人であるスク リプス研究所（カリフォルニア州ラホー ヤ）のKevin Morrisは、この発現抑制 が起こる仕組みを研究し続けており、Li とPlaceの置かれた立場に同情している。 「2004年には私も同じ立場だった。半数 の人々は研究に賛同してくれたが、残り 半数の人々には大ボラを吹いていると思 われていた」とMorrisはいう。「実に苛 立たしい状況だ」。

確かに苛立たしいことだ。このNews Feature 記事の締め切りが迫ったころ、 Placeは、miRNA活性化に関する同研 究グループの論文原稿が却下されたとい う知らせを受けた。その理由は、「作用 機序の説明がなく、証拠不十分」だから であった。それでもしiは依然として、研 究界が態度を変えて自分たちに同意する ようになるはずだと確信している。「我々 は、RNA活性化が生体に本来備わって いる仕組みであると確信している」と彼 はいった。Placeは、それを聞いて驚い たようすも見せなかった。「我々は、そ の作用機序が行き詰まりの根源になるだ ろうとわかっていた。実証するのが最も
困難な部分だからだ。」しかし彼は、自 分の研究グループのデータをほかの研究 者に一目見せることさえできれば、その 強い証拠で説得できるはずだと予言し た。「査読までもち込めれば大丈夫だろ う」とPlaceは述べた。

RNA干渉が科学の世界に登場したと き、人工の産物だと片付けられた段階か ら、革新的パラダイムとしての地位を確 立するまで、かなりの時間がかかった。 PlaceやLi、そして共同研究者たちが、 この革命的パラダイムを書き換えるか、 少なくとも改善しようとするとき、彼ら の前には同じように苦しい闘いが待ち受 けることになる。頑固、自信満々、それ とも楽観主義。どうよばれようとも、こ の研究グループはあきらめようとしない だろう。

Erika Check はサンフランシスコに拠点を置く Nature のライター。

1. Fire, A. et al. Nature 391, 806-811 (1998)

2. Elbashir, S. M.et al. Nature 411, 494-498 (2001)

3. Check, E. Nature 442, 614-615 (2006).

4. http://microrna.sanger.ac.uk/sequences

5. Wassenegger, M. Cell 76, 567-576 (1994)

6. Li, L. C. Proc. Natl Acad. Sci. USA 103, 17337-17342 (2006)

7. Janowski, B. A. et al. Nature Chem. Biol. 3, 166-173 (2007)

8. Morris, K. V. Science 305, 1289-1292 (2004). 